\title{
PerCursos
}

\section{Patrimônio urbano, memória e resistência: os casos de Pilar, Crixás e Porangatu (GO)}

\begin{abstract}
Resumo
O artigo apresenta um contraponto entre as práticas de conservação patrimonial e a condição de 'esquecimento' de muitos núcleos históricos urbanos em Goiás. A base empírica da pesquisa ocorreu em três cidades goianas, onde a ocupação e o povoamento remetem ao ciclo do ouro na região: Pilar de Goiás, Crixás e Porangatu. Nessas cidades foram realizados trabalhos de campo entre 2014 e 2017, orientados pela Pesquisa Participante e pelas técnicas da História Oral. Também foi feita uma pesquisa documental na Superintendência Regional do IPHAN, em Goiás, e nas prefeituras municipais. Nelas se observa um processo gradual de deterioração do acervo do patrimônio edificado, seja por parte do poder público local, da própria comunidade, como também por parte dos órgãos estaduais e federais de preservação. Entretanto, também se observa a resistência do patrimônio pelo viés da memória, a qual, na realidade das cidades estudadas, se manifesta a partir de práticas constituintes do lugar. A resistência do patrimônio urbano não se restringe à permanência material desses elementos, mas sim em como estes se situam na percepção cotidiana das populações, estabelecendo os lugares na significância histórica do presente.
\end{abstract}

Palavras-chave: Goiás - História. Patrimônio cultural. Pilar de Goiás. Crixás. Porangatu

\author{
Luana Nunes Martins de Lima \\ Doutora em Geografia pela \\ Universidade de Brasília - UnB. \\ Professora da Universidade \\ Estadual de Goiás - UEG. \\ Brasil \\ prof.luanunes@gmail.com
}

\author{
Para citar este artigo: \\ LIMA, Luana Nunes Martins de. Patrimônio urbano, memória e resistência: os casos de Pilar, Crixás e \\ Porangatu (GO). Revista PerCursos, Florianópolis, v. 20, n.42, p. 29 - 67, jan./abr. 2019.
}

http://dx.doi.org/10.5965/1984724620422019029 


\title{
Urban heritage, memory and resistance: the cases of Pilar, Crixás and Porangatu (GO, Brazil)
}

\begin{abstract}
The article presents a counterpoint between the heritage conservation practices and the condition of 'forgetting' of many urban historical nuclei in Goiás (Brazil). The empirical basis of the research occurred in three cities in Goiás, where occupation and settlement refer to the gold cycle in the region: Pilar de Goiás, Crixás and Porangatu. In these cities, fieldwork was carried out between 2014 and 2017, guided by the Participant Research and Oral History techniques. Also, a documentary research was done in the Regional Supervision of the IPHAN, in Goiás, and in the city halls. In them there is a gradual process of abandonment of the built heritage, either by the local public authority, by the community itself, or by the state and federal preservation agencies. However, it is also observed a resistance of the heritage by the memory bias, which, in reality of the cities studied is manifested from constituent practices of the place. The resistance of the urban heritage is not restricted to the material permanence of these elements, but rather to how they are daily perceived by the populations, setting the places in the historical significance of the present.
\end{abstract}

Keywords: Goiás (Brazil) - History. Cultural heritage. Pilar de Goiás. Crixás. Porangatu. 


\section{Introdução}

Neste artigo, busco estabelecer, a partir dos estudos de caso realizados em três cidades do interior goiano, os contrastes e os pontos de convergência entre o esquecimento legado ao patrimônio cultural em grande medida não reconhecido institucionalmente nestas cidades, senão de forma seletiva e parcial; e a memória, que traz em si o reconhecimento e a apreensão do passado, como elemento que ainda orienta o presente.

A base empírica da pesquisa que resultou neste artigo ocorreu de forma localizada e aprofundada em três cidades goianas, onde a ocupação e o povoamento deram-se no contexto da mineração. São elas: Pilar de Goiás (situada na região do Vale do São Patrício, microrregião de Ceres, no Centro Goiano), Crixás (situada na microrregião de São Miguel do Araguaia, Noroeste Goiano) e Porangatu (Norte Goiano). Em suma, são cidades cujas histórias reconstroem o processo pelo qual os valores modernos fixaram-se no sertão. Cidades que, experimentando os embates próprios da modernidade, neles mesmos encontram caminhos e estratégias, inventando e reinventando os espaços de experiência e de afirmação da identidade.

A escolha dessas cidades pode ser explicada, inicialmente, pelas evidências de um processo em curso de deterioração do acervo do patrimônio edificado, seja por parte do poder público local, da própria comunidade, como também por parte dos órgãos estaduais e federais de preservação.

A coleta de dados se deu, inicialmente, por meio de um levantamento dos bens tombados em Goiás, pelo IPHAN e pelo Estado, da década de 1930 até o momento atual, seguido de um mapeamento, por meio de trabalhos de campo e pesquisa documental (leis de tombamento do município, Plano Diretor, etc.), do patrimônio histórico, tombado ou não, de Pilar de Goiás, Crixás e Porangatu, a fim de fazer uma leitura de sua atual situação. Esse primeiro levantamento envolveu os elementos representativos de memória das cidades, tais como as edificações, os conjuntos arquitetônicos, os monumentos, as igrejas, as praças, os chafarizes, os sinos, os museus, as festividades e outros elementos tradicionais. O mapeamento se deu por meio de registros fotográficos, 
investigação de documentação, entrevistas e levantamento dos registros de bens tombados.

A pesquisa no arquivo técnico da superintendência do IPHAN em Goiás permitiu o acesso a todo material referente às cidades Pilar de Goiás, Crixás e Porangatu, no que se refere à abertura ou solicitações de processos administrativos para tombamentos, ou projetos submetidos à seleção de editais de chamamento público para a salvaguarda do patrimônio material e/ou imaterial, relatórios de viagens, correspondências trocadas entre gestores locais, superintendentes regionais e outros.

Outra importante etapa metodológica foram os trabalhos de campo in loco conduzidos pela abordagem da pesquisa participante, sugerida por Brandão (1990), e pela história oral, orientada por Delgado (2010). Estas, foram fundamentais para identificar quais são os elementos que denotam a resistência do patrimônio a partir da memória local e qual é a representatividade desse patrimônio para os moradores na constituição do lugar.

Os trabalhos de campo foram realizados em períodos diferenciados, entre 2014 e 2017, e concentrados em visitas particulares aos núcleos considerados como patrimônio arquitetônico e aos monumentos, aos centros culturais, aos moradores previamente selecionados (pessoas pioneiras, tradicionais ou referências culturais locais) e aos agentes responsáveis pelas questões que tocam ao patrimônio nas três cidades. Além disso, os períodos das pesquisas de campo também foram selecionados de acordo com a ocorrência de manifestações culturais expressivas nas cidades, como a Festa de Nossa Senhora do Pilar e as Cavalhadas em Pilar de Goiás, as festas do ciclo natalino que incluem as tradicionais novenas e visitação de presépios em Pilar, a Festa do Divino Espírito Santo em Crixás e Pilar de Goiás, a Festa da Boa Vizinhança e o Arraial do Descoberto, em Porangatu, entre outras.

A pesquisa privilegiou a análise geográfica do patrimônio nessas três cidades, refletindo sobre o mesmo a partir da totalidade urbana. A ligação dos sujeitos com o lugar, numa perspectiva de enraizamento e identidade, foi o que amadureceu o entendimento do que é o patrimônio e do que efetivamente resiste como patrimônio do 
lugar. E assim, tomando como referência as noções de memória e esquecimento, foi possível associar as relações de poder que envolvem o pretérito-presente da exclusão sociocultural e política do patrimônio e dos grupos.

Mais do que uma análise restrita ao que restou do patrimônio histórico material na paisagem dessas cidades e das ações de preservação institucional, foi objetivo evidenciar as relações sociais de uso dos patrimônios culturais para compreender a forma como sua apropriação por parte das populações locais constitui-se como formas de resistências às supostas ameaças ao patrimônio, a saber: a modernização do território, o uso mercadológico, ou ainda, a negligência política e institucional.

Como bem pontuou Paes uma análise geográfica e crítica sobre o patrimônio nas cidades históricas "descentraliza as teorias ligadas ao restauro, ou às formas, e põe em evidência as relações sociais de uso destes patrimônios culturais, de modo a revelar a apropriação e a reprodução do lugar, em permanente resposta, domínio ou resistência às verticalidades a ele impostas." (PAES, 2012, p. 320). Afinal, a patrimonialização oferece o sentido de continuidade da história pela preservação e reprodução social do passado, mas "é no presente que a trama da vida é tecida, permanentemente, com os objetos, as ações e os sentidos da realidade socioespacial” (PAES, 2012, p. 320).

\section{Breve contextualização sobre a questão do patrimônio em Goiás}

Em muitas cidades no interior goiano, a perspectiva do patrimônio cultural, tanto para os escassos órgãos responsáveis pela preservação (secretarias ou agências de cultura) como para estudiosos e pesquisadores locais, sempre transcorre da noção de uma historiografia que deixou lacunas, considerando o fato de poucos vestígios materiais terem sido preservados. Pouco se pensa nesse patrimônio pelo viés do presente e de como ele se incorpora ao usufruto das ações cotidianas.

Como evidenciado por Lima (2017), parte significativa do patrimônio goiano apresenta os resultados de processos políticos, econômicos e sociais que o marginalizaram na história. No início do século XX, ao mesmo tempo em que Goiás se 
tornava uma centralidade, segundo os ditames das políticas que visavam à integração nacional, tornava-se um celeiro de periferias - pela criação de subcentros regionais e pela marginalização de diversos outros núcleos urbanos que não foram contemplados por políticas de preservação e restauro. Apesar de o estado de Goiás ser constituído, em grande medida, por cidades relativamente recentes, fundadas ou emancipadas no século XX, há muitas cujos primórdios de ocupação e fundação remetem ao ciclo do ouro. A tabela abaixo apresenta estas cidades e povoados, sem incluir os que hoje compõem o território do estado do Tocantins.

Tabela 1 - Cidades e povoados do território goiano fundados no Ciclo do Ouro

\begin{tabular}{|c|c|c|}
\hline Cidades & Ano de Fundação & Denominação antiga \\
\hline $\begin{array}{l}\text { Santo Antônio do } \\
\text { Descoberto }\end{array}$ & 1722 & Arraial de Santo Antônio do Descoberto \\
\hline Crixás & 1726 & $\begin{array}{l}\text { Povoado de Nossa Senhora da } \\
\text { Conceição }\end{array}$ \\
\hline Pirenópolis & 1727 & Antigo Arraial de Meia Ponte \\
\hline Goiás & 1729 & $\begin{array}{l}\text { Antigo Arraial de Sant'Anna / Vila Boa de } \\
\text { Goiás }\end{array}$ \\
\hline Guarinos & 1729 & Antigo povoado Gorino \\
\hline Santa Cruz de Goiás & 1730 & Antigo Arraial de Santa Cruz \\
\hline Corumbá de Goiás & 1731 & Corumbá \\
\hline Traíras & 1735 & Hoje, na categoria de povoado \\
\hline Catalão & 1736 & Região denominada Borda da Mata \\
\hline Cavalcante & 1740 & Cavalcante \\
\hline São Francisco de Goiás & 1740 & $\begin{array}{l}\text { Antigo povoado São Francisco das } \\
\text { Chagas }\end{array}$ \\
\hline Pilar de Goiás & 1741 & Quilombo de Papuã / Pilar \\
\hline Mara Rosa & 1742 & Antigo povoado de Amaro Leite \\
\hline Porangatu & Entre 1744 e 1754 & Antigo Arraia do Descoberto \\
\hline Mossâmedes & 1755 & $\begin{array}{l}\text { Antiga Aldeia de São José de } \\
\text { Mossâmedes }\end{array}$ \\
\hline Iporá & 1748 & Antigo Arraial de Pilões \\
\hline Niquelândia & 1755 & $\begin{array}{c}\text { Antigo povoado de São José do } \\
\text { Tocantins }\end{array}$ \\
\hline Luziânia & 1759 & Antigo povoado de Santa Luzia \\
\hline Formosa & 1760 & Antigo Arraial de Couros \\
\hline Monte Alegre de Goiás & 1769 & Antigo Arraial do Morro do Chapéu \\
\hline Silvânia & 1774 & Antigo Arraial de Bonfim \\
\hline Jaraguá & 1785 & Antigo Arraial do Córrego do Jaraguá \\
\hline São Domingos & fins do séc. XVIII & Antigo Arraial Velho \\
\hline
\end{tabular}

Fonte: IBGE (Cidades). Organizado e adaptado pela autora. 
Algumas dessas cidades ou povoados, por seu posicionamento geográfico ou político, foram inseridos em novas atividades, que alavancaram o desenvolvimento econômico e a modernização de seu território, sobretudo no contexto da Marcha para o Oeste (CHAUL, 2010). Outras, por sua vez, refletem uma situação de relativo abandono e estagnação populacional, por não terem se inserido nos eixos de desenvolvimento, fato que se soma à negligência em relação a parte considerável do patrimônio material ainda existente. Muitas edificações que remontam ao ciclo do ouro estão em ruínas, foram parcialmente ou totalmente modificadas, ou já foram demolidas.

Em Crixás, apenas um casarão foi tombado isoladamente em nível municipal, havendo escassas reminiscências da cultura material na malha urbana. Em Porangatu, o perímetro do sítio histórico foi tombado pelo governo municipal em 1984, mas a lei de tombamento não é aplicada na prática local, por isso pouco restou da arquitetura colonial original. Em Pilar de Goiás, em que se nota atualmente uma preocupação maior, o polígono de tombamento está em processo de estudo desde o fim da década de 1990 para ratificar as áreas de real interesse de preservação do Instituto do Patrimônio Histórico e Artístico Nacional (IPHAN), sendo que muito do que havia de bens edificados se perdeu da década de 1960 para cá. Alguns bens foram refuncionalizados para atividades culturais e passaram por restauros. Outra parte dos bens, sem fiscalização ou manutenção efetiva, está em deterioração ou já foi destruída para dar lugar a outros tipos de construções. Esses bens estão discriminados pormenorizadamente adiante, em tabela referente aos bens tombados em Pilar de Goiás.

Essa é uma das faces do esquecimento tratadas por Lima (2017) - a condição marginal dessas cidades no que se refere às políticas de patrimonialização do Estado. Ausentes na agenda estratégica de desenvolvimento prevista no Programa de Aceleração do Crescimento - PAC Cidades Históricas ${ }^{1}$, tais cidades caracterizam-se ainda pela evidente

\footnotetext{
1 O PAC (Programa de Aceleração do Crescimento) Cidades Históricas foi lançado pelo governo federal em outubro de 2009 em Ouro Preto (MG). O programa é uma ação voltada aos municípios com conjuntos ou sítios protegidos em âmbito federal e, ainda, cidades com bens imateriais registrados como patrimônio cultural do Brasil. Para integrar-se ao PAC, o município, em conjunto com o estado e o IPHAN, deve elaborar um Plano de Ação que defina um planejamento integrado, coerente com o Sistema Nacional do Patrimônio Cultural, e com ações sobre o território pactuadas com os diferentes órgãos governamentais e a sociedade (BRASIL, 2011).
} 
ausência de uma estrutura institucional de preservação que possibilite o uso democrático do patrimônio cultural.

Para Costa e Suzuki (2012), a seletividade imposta, tanto no processo de modernização do território brasileiro quanto nas variantes estéticas que projetaram algumas cidades coloniais, fez com que se tornassem 'esquecidos' muitos grupos sociais e núcleos urbanos. Em Goiás, conforme esclareceu Costa e Steinke (2013), esse movimento legou maior ênfase e centralidade à Cidade de Goiás (antigo Arraial de Sant' Anna - 1726) e a Pirenópolis (antigo Arraial de Nossa Senhora do Rosário da Meia Ponte 1729), que adquiriram um caráter imagético e maior notoriedade midiática em âmbito regional e nacional. Entre outras razões elencadas, essas cidades foram as primeiras da história da mineração do ouro em Goiás a terem seus núcleos tombados pelo Instituto do Patrimônio Histórico e Artístico Nacional (IPHAN). Os autores evidenciaram que cidades que datam dos primórdios da ocupação pela exploração aurífera, algumas em vias de alcançar a marca do terceiro centenário, apesar dos acúmulos temporais presentes, apresentam-se como um patrimônio sem tanta expressividade no campo das estratégias do Estado, sobretudo em relação ao turismo. Isso porque as políticas de patrimonialização privilegiaram os lugares e objetos símbolos que demarcavam o papel das elites urbanas e rurais pretéritas que forjaram uma ideologia espacial de consagração da nação, conforme afirma Costa (2012) em estudo posterior.

Chuva (2009) denuncia a hegemonização de uma determinada prática seletiva no que se refere ao tratamento do patrimônio brasileiro, tombado nos primeiros anos do SPHAN (Serviço do Patrimônio Histórico e Artístico Nacional). Embora se saiba que essa prática ocorrera durante toda a gestão de Rodrigo Mello Franco de Andrade (1937 a 1967), "a feição dada ao patrimônio histórico e artístico nacional, a qual se reproduziu posteriormente, foi delineada e consagrada ainda nas décadas de 1930 e 1940" (CHUVA, 2009, p. 207), pois depois desse período o número de tombamentos no território nacional reduziu drasticamente, com exceção do estado de Minas Gerais, conforme apontam os dados da autora. Nesse período, os Estados de Goiás, Mato Grosso, Amazonas, Acre, Ceará e Maranhão não foram contemplados com tombamentos, e nem inseridos na organização dada aos novos distritos pelo Regimento Interno da Diretoria do Patrimônio 
Histórico e Artístico Nacional (DPHAN), de 1946. Segundo Chuva (2009, p. 218-19) “isso se deu não só pelas dificuldades de acesso a essas regiões distantes da Capital Federal, mas, principalmente, por serem consideradas como regiões 'distantes da civilização', sem construções significativas".

Corroboro a ideia de Jeudy (2005), para quem a conservação patrimonial, por si só, não é capaz de alimentar os sentidos que o patrimônio carrega. Para o autor, por vezes, a conservação só traz como compensação a nostalgia; o risco do esquecimento engendra a culpa e legitima os projetos de revisitação da história, que, na busca excessiva pelas raízes, anulam a vida presente.

Ainda se ouve falar que a conservação assegura, de alguma maneira, o trabalho de luto. Trabalho que se torna necessário para que possamos suportar o desaparecimento. Bastaria conservar tudo para que a mente se mantivesse tranquila? A conservação patrimonial se encarrega do depósito das lembranças e nos libera do peso das responsabilidades infligidas à memória. A profusão de locais de memória oferece uma garantia real contra o esquecimento. Mas esse trabalho de luto, se exercido em demasia, não corre o risco de provocar excesso de tranquilidade nas memórias coletivas? O "dever de memória" que hoje nos é imposto instaura um estado culpabilizante estimulado pela necessidade moral da rememoração. Não temos mais liberdade de esquecer, pois isto seria um crime. "Esquecer é ocultar", tal seria a nova regra de uma boa gestão de memórias. Censuramos as gerações que nos precederam por terem tão facilmente esquecido. É provável que elas tenham achado possível viver o tempo presente tal como ele era. A partir de agora é provável que a lembrança nos faça sentir culpados, que ela nos provoque vergonha, vergonha causada pelo simples desejo de esquecer. (JEUDY, 2005, p. 15)

De acordo com Ricoeur (2007), o passado não existe, é representação. Só existe enquanto presente, somente pode ser acessado no presente a partir do reconhecimento de rastros. Só pode ser apreendido pela lembrança. E mesmo a lembrança é um ato de seleção. O esquecimento seria causa de angústia e temor existencial, por remeter à perda de algo que, em algum momento específico, fora experimentado. Entretanto, o esquecimento traz em si um efeito dialógico, pois, não fosse sua oposição à lembrança, como seria possível trazer eventualmente, à realidade imagética, coisas ou fatos de 
outrora? O vir-a-ser no âmbito da memória seria neutralizado por um tipo de memória plena, ou seja, uma consciência constante de tudo quanto temos experimentado. Se por um lado somos amedrontados pela condenação de esquecermos tudo, "saudamos com uma pequena felicidade o retorno de um fragmento do passado arrancado, como se diz, ao esquecimento. As duas leituras prosseguem no decorrer de nossa vida - com a permissão do cérebro" (RICOEUR, 2007, p. 427).

A culpa que sucedeu após longo período de esquecimento é um fato que aparece de forma evidente nas cidades pesquisadas. Os relatos abaixo são os argumentos de entrevistados moradores de Crixás ao serem questionados sobre a atitude da população local na ocasião das demolições de edificações antigas de Crixás, ocorridas na segunda metade do século XX.

Eles não tinham consciência que aqui era a história de um povo, porque se tivesse não tinha deixado derrubar. Então, se eles não tinha consciência, não sentia falta. [...] Tem o nome de Crixás que é histórico, mas na realidade a história de Crixás é muito pequena em material. Fisicamente é muito pequena, porque destruiu as casas que tinha. [...] Então, nessa altura, faz falta, né? Faz falta... (FERREIRA NETO, 2015, informação oral)

Aqui ó, tinha a casa dos meus avós, bisavós, avós, foi passando um pra outro, né? Essa daí, esse que é prefeito hoje, Dr. Orlando, no primeiro mandato dele, ele tentou muito não deixar demolir ela, até propôs pra família que ele fazia uma parceria com eles pra reformar até um ponto que fizesse um patrimônio tombado, né? Mas eles não quiseram, eles não quiseram! Eles quis foi demolir mesmo, deixou ela acabar. Essa aí não foi falta de achar quem quis ajudar. (NEVES, 2015, informação oral)

A Casa Grande foi construída pelos escravos, as casas aqui também foram. Cada fechadura desse tamanho assim! Então, não tínhamos a menor condição, [...] não tínhamos cultura suficiente pra valorizar, não tínhamos recursos, a cidade era muito pobre, havia mais escambo [...] do que moeda corrente, [...]. Muita pobreza e muita desigualdade social. [...] Não havia conservação, cada uma que derrubava, eu batia palma, era um fedor a menos, eram menos morcegos. (FERREIRA, 2015, informação oral)

[...] as nossas cidades [...] não tinham despertado ainda esse sentimento de cultura, de folclore. Infelizmente, quando nós acordamos pra isso, 
muita coisa já tinha derrubado. Não teve como voltar atrás, continuar. [...] Eu não sei se em toda cidade foi assim, mas pelo menos na nossa aqui foi assim. [...] A cidade tinha um status [...], teve pelo ouro, [...] a própria comunidade tinha uma certa importância, condição né? [...] A comunidade da época tinha um grande número de pessoas que destacavam, assim, que queria desenvolver, que construía. Tinha uns que, às vezes, ficavam [...] sem querer progredir, mas a maioria do pessoal já tinha aquela coisa de progresso, porque ia pra Goiás, ia pra cidades vizinhas, então via, conhecia as coisas. Então queria fazer também, melhorar também. Agora, por outro lado, já não teve esse desenvolvimento, deixou as coisas ir acabando. (FARIA2, 2016, informação oral)

As narrativas ressoam ora como desejo nostálgico no presente, ora como justificativa para as ações do passado, pela inconsciência de um povo que vivia em um tempo no qual se buscava fugir da ideia de "atraso3". Um tempo em que Goiás, no limite, tentava romper com esse estereótipo, enquanto, em nível nacional, as práticas institucionais de patrimonialização e de preservação já se faziam prementes.

A reconstrução da ideia de "decadência" na representação do "atraso" apregoava a urgência pela modernização que serviria para a consolidação do Estado-nação brasileiro. Segundo Chuva (2012, p. 68):

[...] hábitos e costumes do povo deveriam ser induzidos ao desaparecimento, do mesmo modo que os vestígios materiais do período colonial eram apagados pelas reformas urbanas realizadas. Essas estratégias de apagamento, para além das grandes reformas e demolições na capital, se davam também na arquitetura vernacular, nas pequenas reformas em edificações particulares, nas quais eram incorporadas platibandas às fachadas dos imóveis - com isso obtinha-se um ar moderno e se escondiam os velhos telhados.

\footnotetext{
${ }^{2}$ Presidente da Associação de Catireiros e Foliões de Crixás.

$3 \mathrm{Na}$ literatura revisada, é notório o vínculo indissociável entre a tipologia do barroco encontrada nas cidades da mineração e a imagem de atraso, decadência e isolamento (ETZEL, 1974; FREITAS, 2011), apregoada pela historiografia de Goiás, construída sobre as bases de relatos de viajantes, sobretudo no período pós-mineratório.
} 
Apesar das trajetórias nas quais se identifica uma condição de esquecimento do patrimônio das cidades goianas em questão, há, em contrapartida, a resistência a essa condição, que é consolidada pela memória coletiva; é ela o que dá sentido a esse patrimônio. A resistência do patrimônio não se traduz pela ideia de que o passado está presente, intacto, não incorporando outras formas, ou não se ressignificando ante o processo de modernização. Ela é a própria memória, que estabelece o elo entre o passado e o presente, gerando sentidos de patrimonialidade ${ }^{4}$ pelo lugar, ainda que este não seja reconhecido institucionalmente (seja por meio de leis de tombamento, seja por investimento em restauro, ou ainda por ações locais de educação patrimonial). Os diálogos entre os lugares e as ações que engendram seus moradores, por fim, desvelaram essa resistência.

\section{Patrimônio e memória na paisagem urbana de Pilar, Crixás e Porangatu}

Lima (2017) apresenta um levantamento de tudo o que foi possível observar, acompanhar localmente ou em registros a respeito do patrimônio das cidades pesquisadas, da contextualização histórica e a descrição de seus lugares identificados como espaços de memória, a partir da leitura, da escuta sensível e do exercício do olhar. Nas primeiras pesquisas de campo já foi possível identificar a ausência de políticas de preservação que tratem dos referidos núcleos históricos 5 . Mas, de igual modo, a memória

\footnotetext{
${ }^{4}$ Para além da patrimonialização (que nem sempre se efetiva no lugar), considero oportuno uma reflexão sobre a "patrimonialidade", termo cunhado por Dominique Poulot (2009), entendido como reconhecimento, apropriação e valoração do bem pelos sujeitos que o vivenciam e o representam. Poulot (2009, p. 28) diferencia a patrimonialidade do fenômeno de patrimonialização, designando a primeira como "a modalidade sensível de uma experiência do passado, articulada com uma organização do saber identificação, atribuição - capaz de autenticá-lo".

${ }^{5}$ Utilizo o conceito de núcleo histórico para me referir ao conjunto das estruturas físicas e humanas de valor histórico contido nas cidades, por entender que no termo "cidade histórica", conforme Argan (1998), não deve haver separação entre a zona antiga e a zona moderna. Para este autor, o termo "cidade histórica" limita o entendimento da cidade real, adotando a premissa de que a cidade moderna cresce sem grandes preocupações qualitativas, enquanto que a cidade histórica se torna encerrada, estagnada. "Esta ruptura de continuidade ou a impossibilidade de desenvolvimento que gera a artificiosa concentração da historicidade intrínseca da cidade no núcleo antigo, dando-se assim por aceito que este é, por definição, histórico, do mesmo modo que o moderno [...], em sua realidade e atualidade, seria por definição não-histórico ou mesmo anti-histórico" (ARGAN, 1998, p. 74). Assim, núcleo histórico abarca edificações e agregados, o tecido viário, a paisagem, a população local residente e suas manifestações e
} 
sobre o lugar que transborda em seus sujeitos, nos "saberes" e nos "fazeres", no orgulho sobre o que se mantêm e na saudade do que não existe mais.

Os bens patrimoniais que resistem na paisagem urbana são fundamentais para uma primeira análise, pois são elementos reatualizados de forma particular pelo trabalho da memória. A memória, portanto, é um conceito fundamental para a análise proposta.

Halbwachs (2003) destaca que ela está associada ao espaço, ou seja, o espaço ancora as lembranças do vivido. Para o autor (2003, p. 172), "a memória [...] se baseia na permanência do espaço ou, pelo, menos, na permanência da atitude adotada pelo grupo diante desta porção do espaço". Ele ainda ressalta que, "quando um grupo humano vive por muito tempo em um local adaptado a seus hábitos, não apenas seus movimentos, mas também seus pensamentos se regulam pela sucessão das imagens materiais que os objetos exteriores representam para ele" (p. 163). E, ainda a respeito disso, Halbwachs (2003, p. 159-160) explica o papel que as imagens espaciais desempenham na memória coletiva.

Quando inserido numa parte do espaço, um grupo o molda à sua imagem, mas ao mesmo tempo se dobra e se adapta a coisas materiais que a ela resistem. $O$ grupo se fecha no contexto que construiu. A imagem do meio exterior e das relações estáveis que mantém com este passa ao primeiro plano da ideia que tem de si mesmo. [...] Cada aspecto, cada detalhe desse lugar tem um sentido que só é inteligível para os membros do grupo, porque todas as partes do espaço que ele ocupou correspondem a outros tantos aspectos diferentes da estrutura e da vida de sua sociedade, pelo menos o que nela havia de mais estável.

Pilar de Goiás, Crixás e Porangatu se revelam pelas paisagens, atuais e de outrora, em uma sucessão de imagens que indicam claramente a transição de "cidade colonial" para "cidade moderna". A paisagem da cidade constitui-se de fragmentos de tempos históricos superpostos, como foi posto por Santos (1988), e essa mudança ocorre também nas funções e nos costumes sociais. 
Halbwachs oferece argumentos para refletir sobre os efeitos das transformações do espaço para os processos sociais de elaboração da memória, apontando que a permanência das formas de vida se revela no vínculo da sociedade com seus espaços de memória. Para o autor, “os costumes locais resistem às forças que tendem a transformálos e essa resistência permite entender melhor a que ponto nesse tipo de grupo a memória coletiva se apoia nas imagens espaciais" (HALBWACHS, 2003, p. 162). Disso resulta o entendimento de alguns indivíduos de que se fazem necessárias ações de intervenção para que essas mudanças nos núcleos históricos não ocorram de forma irrefletida, como sugere o seguinte relato, referente a Porangatu:

Subindo essa avenida ali, Floriano Peixoto, ali tem a Art Decó, a gente mostra os predinhos, né. Mas mesmo assim a gente vê que tá sofrendo, quando outro empresário compra, eles derrubam para fazer ponto comercial e a gente tenta ir atrás pra ver se a gente consegue uma sensibilização, e isso é o que a gente tá propondo. Propomos à Secretaria Municipal de Educação uma disciplina para o ano que vem, na qual os alunos vão começar a estudar o patrimônio histórico, como sendo uma das vertentes, né, dentro do conteúdo programático, pra que se tenha conhecimento, gere amor e, gerando amor, gere proteção em cima dele. (ABREU ${ }^{6}, 2015$, informação oral)

Essas ações voltadas para as novas gerações devem estar articuladas à compreensão da memória dos moradores mais antigos, no sentido de validar a correspondência entre o espaço temporalizado e o cotidiano citadino. A paisagem das cidades oferece uma historicidade materializada em antigos casarões, igrejas, monumentos e outros. São traços do passado relacionados aos aspectos morfológicos da organização espacial da cidade e que podem também representar os valores, tradições e símbolos das pessoas que a habitam.

Do ponto de vista da antropologia urbana, Rocha e Eckert (2007, p. 348-9) argumentam que

\footnotetext{
${ }^{6}$ Adair José Ataídes de Abreu foi secretário de Cultura e Turismo de Porangatu no período em que ocorreu a entrevista.
} 
[...] os bens patrimoniais que constituem uma cidade configuram-se não apenas num espaço construído e edificado, mas nos saberes, fazeres e tradições que se apresentam ordinariamente no interior das manifestações culturais de seus habitantes, os quais não são contemplados nos regulamentos propostos para uma política de defesa de patrimônio cultural no meio urbano. As ações discursivas que fazemos [antropólogos urbanos] acerca de uma política de preservação e de conservação de bens arquitetônicos e urbanísticos de uma cidade - bens edificados que configuram uma paisagem urbana - enraízam-se no espaço dos seus territórios-mitos, criando, em seu contexto, uma hierarquia e configurando a cidade qualitativamente em lugares carregados de sentido.

Em uma partilha comum, são esses sentidos que geram identidade e valoração dos moradores locais com seus bens patrimoniais, bem como o desejo de preservação. Da mesma forma, a preservação não apenas permite o trabalho da memória (RICOEUR, 2007) como uma chave hermenêutica para adentrar ao que era o universo passado, mas também fortalece a permanência de alguns tipos de saberes, tradições, manifestações culturais e relações sociais pautadas num sentido de comunidade7. Ainda existe um grau de integração social que as cidades totalmente modernizadas perderam, um acesso não apenas ao domínio do material, mas, principalmente, ao conteúdo simbólico. Como observou Halbwachs (2003), não são apenas as igrejas, casarões e monumentos que persistem através dos séculos, mas os modos de vida das pessoas que estão em permanente contato com eles e confundem sua vida com a vida das coisas.

Ao adentrar no terreno da Geografia para a compreensão da memória a partir da categoria de análise "paisagem", alguns autores oferecem importantes contribuições. Para Abreu (1998, p. 83), a memória individual e coletiva pode contribuir para a recuperação da memória das cidades, pois “a partir dela, ou de seus registros, pode-se enveredar pelas lembranças das pessoas e atingir momentos urbanos que já passaram e formas espaciais que já desapareceram". Esse autor declara que os termos "memória urbana" e "memória da cidade" se referem não à capacidade de lembrar dos indivíduos

\footnotetext{
7 A ideia de "comunidade" remete a sentimentos associados à segurança, estabilidade, acolhimento e costume. Bauman (2003) a nota como um espaço de segurança, conforto e da sensação de algo conhecido das pessoas, para que se crie identidade. Para o mesmo autor, "o anseio por identidade vem do desejo de segurança" (BAUMAN, 2005, p. 35).
} 
ou grupos, mas ao estoque de lembranças que estão eternizadas na paisagem ou nos registros do lugar, e que agora são retomadas pela sociedade.

Scarlato e Costa (2013), por sua vez, apresentam um viés de abordagem do patrimônio urbano em Geografia e reafirmam o esforço que o geógrafo deve empreender na busca pelo "todo" no processo de levantamento empírico-morfológico. Para os autores, "no contexto da vida em cidades (de distintas escalas), o que podemos pesquisar é a essência das relações que tecem a vida urbana e que são embrenhadas no patrimônio ressignificado, reutilizado" (SCARLATO; COSTA, 2013, p. 376-377).

Considerando as perspectivas geográficas de Abreu (1998) e Scarlato e Costa (2013), a leitura dos núcleos históricos de Pilar, Crixás e Porangatu foi ainda realizada incorporando alguns parâmetros definidos por Brito (1998):

1) A localização física no território;

2) A morfologia urbano-arquitetônica;

3) A atividade econômica na região;

4) O significado simbólico para a sociedade.

As três cidades possuem muitos elementos que denotam uma gênese $\mathrm{e}$ configuração histórico-geográfica em comum. A negligência quanto ao patrimônio de pedra e cal aplica-se às três, embora em níveis diferentes de atuação do poder público e em distintas formas de percepção e graus de afetividade pelos moradores. A correspondência feita entre o tratamento dos patrimônios locais e a memória coletiva revelou algumas singularidades.

a) Em Pilar de Goiás - observamos um patrimônio parcialmente mantido/restaurado pelos órgãos de preservação, embora se trate de uma gestão patrimonial que nem sempre se articula com os símbolos e signos reproduzidos pela comunidade local.

O desenvolvimento urbano de Pilar foi pequeno, se comparado com o de outras cidades em Goiás que surgiram posteriormente. Poucas ruas foram acrescentadas à cidade e sua área não aumentou de forma significativa desde o período de fundação. Por 
manter sua condição geográfica de zona central, o núcleo histórico qualifica-se como o centro urbano de Pilar. A respeito de sua morfologia urbano-arquitetônica, não houve manutenção da originalidade de muitas fachadas, do calçamento de pedras, entre outros; mesmo assim, o registro no livro de tombo do IPHAN agrega a área como Conjunto Arquitetônico e Paisagístico, por conservar uma arquitetura setecentista de concepção urbanística do Conselho Ultramarino de Portugal. O núcleo histórico não possui funcionalidade econômica expressiva, se vinculando, sobretudo, à atividade residencial.

Figuras 1 e 2: Antigos casarões mal conservados ou em ruínas, Rua Viracopos, Pilar de Goiás

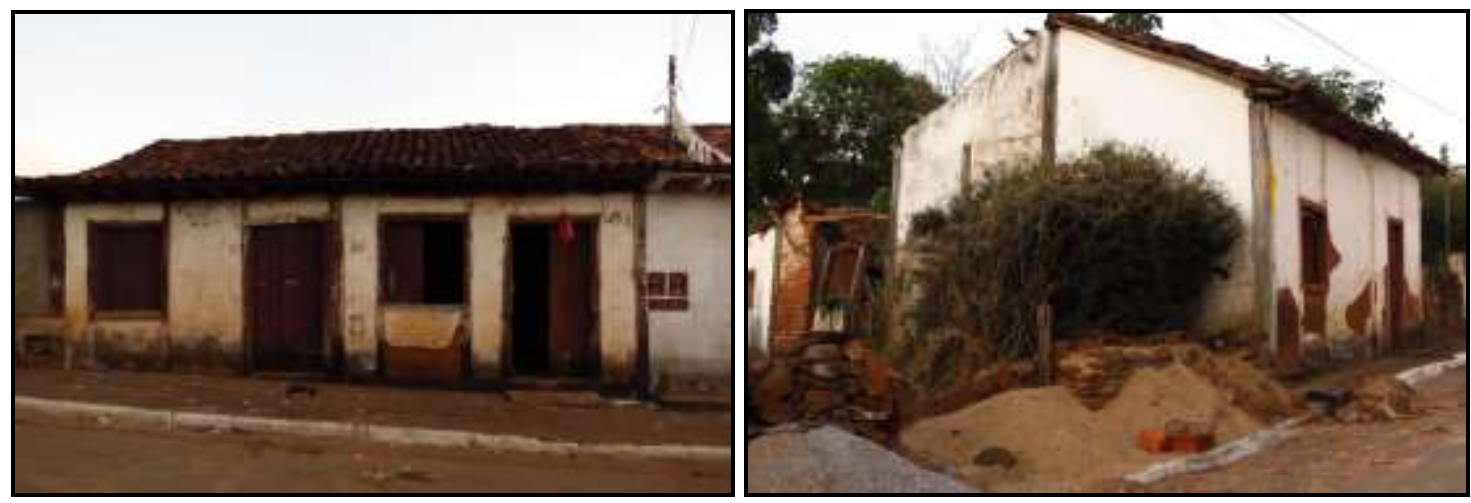

Fotos da autora, 2014.

Atualmente, o núcleo urbano de Pilar não tem mais as características de um antigo arraial do ciclo do ouro, o que havia sido mantido até as primeiras décadas após o tombamento federal, ocorrido em 20 de março de 1954. O rústico calçamento de pedras e outros significativos edifícios sucumbiram ao asfalto e ao "progresso". Muitas moradias, apesar de incluírem-se no perímetro de tombamento, tiveram as fachadas e outras características alteradas. Mesmo assim, é possível identificar que as primeiras casas implantadas delinearam a trama das ruas.

Segundo relatório técnico de avaliação e vistoria da $17^{\text {a }}$ Sub-regional do IPHAN, de 1995, executado pelos arquitetos Silvio Cavalcante e Maria Cristina Portugal Ferreira e pelo engenheiro Walter Villena Valio, as edificações assinaladas no mapa original do perímetro de tombamento foram todas identificadas, sendo que, nesta época (1995), 28 
ainda se mantinham inalteradas, mas apenas oito imóveis foram classificados como de real interesse de preservação:

1) Igreja de Nossa Senhora do Pilar (onde estão os Sinos de Pilar e o Chafariz São José, datado de 1745, sendo o único remanescente dos três chafarizes que abasteciam a cidade);

2) Igreja de Nossa Senhora das Mercês (ou Igreja dos Pardos);

3) Casarão na praça ${ }^{8}$;

4) Casa de Rótulas;

5) Casa de Enxaimel (restaurada em 2015);

6) Casa Setecentista (Museu Casa da Princesa, restaurado entre 2016 e 2017);

7) Casa de Câmara e Cadeia;

8) Casa do Padre Braz.

Figura 3 - Museu Casa da Princesa, Pilar de Goiás

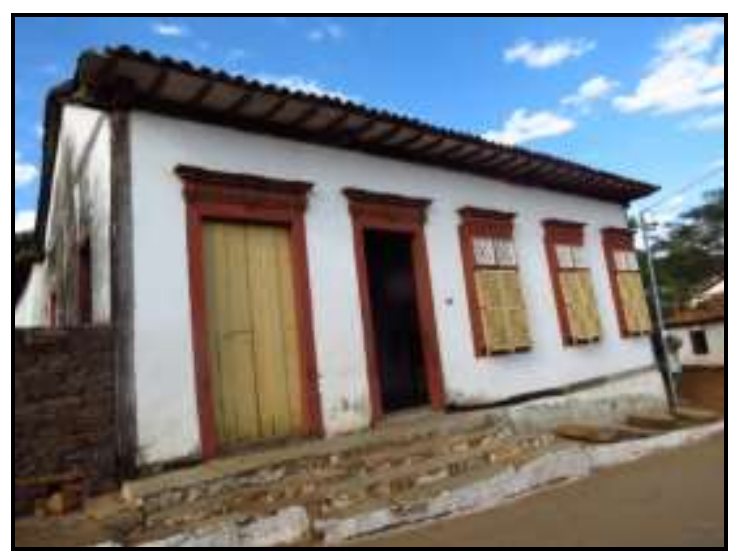

Foto da autora, julho de 2013.

\footnotetext{
${ }^{8}$ Demolido após 1995, quando foi elaborado o relatório.
} 
Figura 4 - Igreja Matriz de Nossa Senhora do Pilar, reconstruída em 1922; Pilar de Goiás

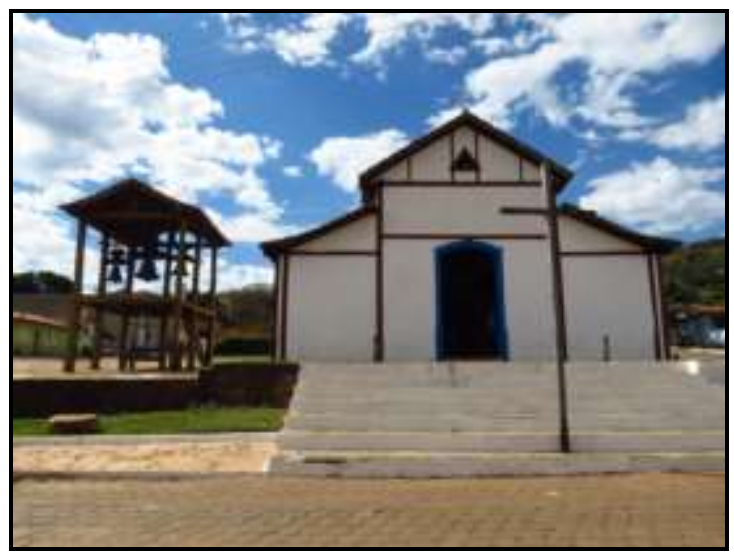

Foto da autora, julho de 2013.

Estes bens estão incluídos nas leis de tombamento elencadas na tabela 2.

Tabela 2 - Relação dos bens tombados em Pilar de Goiás

\begin{tabular}{|c|c|c|c|}
\hline Bem tombado & Proprietário & $\begin{array}{l}\text { Instrumento de } \\
\text { tombamento }\end{array}$ & Localização \\
\hline $\begin{array}{l}\text { Igreja de Nossa } \\
\text { Senhora das } \\
\text { Mercês }\end{array}$ & $\begin{array}{l}\text { Particular } \\
\text { (Diocese) }\end{array}$ & Lei Estadual $n^{\circ} 8.915 / 1980$ & $\begin{array}{l}\text { Largo das Mercês, s/nº. Pilar de Goiás- } \\
\text { GO }\end{array}$ \\
\hline \multirow[b]{2}{*}{ Casa da Princesa } & \multirow[b]{2}{*}{$\begin{array}{c}\text { Poder Público } \\
\text { (Governo } \\
\text { Federal) }\end{array}$} & Lei Estadual $n^{\circ} 8.915 / 1980$ & \multirow[b]{2}{*}{$\begin{array}{l}\text { Rua da Cadeia, 270. Pilar de Goiás - } \\
\text { GO }\end{array}$} \\
\hline & & $\begin{array}{c}\text { IPHAN } \\
\text { Livro de Belas Artes: } 413 \\
\text { № processo: 0458 T-52 } \\
\text { Data: 20/03/1954 } \\
\text { (Anexo 5) }\end{array}$ & \\
\hline \multirow[b]{2}{*}{$\begin{array}{l}\text { Acervo } \\
\text { Arquitetônico e } \\
\text { Paisagístico da } \\
\text { Cidade } \\
\text { (processo de } \\
\text { rerratificação) }\end{array}$} & \multirow[b]{2}{*}{ Diversos } & Lei Estadual n 8.915/1980 & \multirow{2}{*}{ 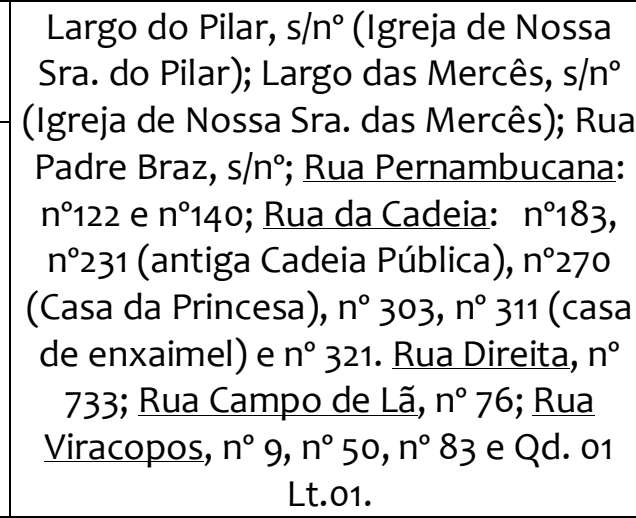 } \\
\hline & & 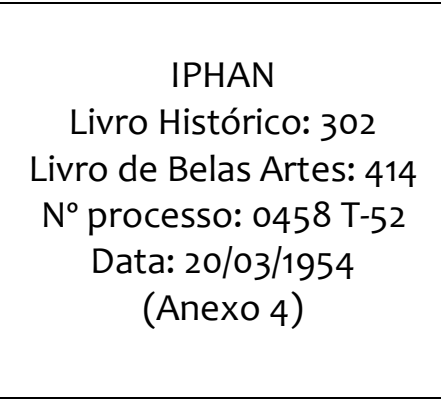 & \\
\hline
\end{tabular}

Fontes: Arquivo Noronha Santos/IPHAN, 2016. Disponível em: http://portal.iphan.gov.br/ans e Secretaria de Estado da Cultura - SECULT Goiás - Superintendência de Patrimônio Histórico e Artístico, 2015. 
A população local, embora carente de recursos para a realização de obras de restauro nos padrões exigidos, não é absolutamente isenta de qualquer engajamento em prol de sua memória, como sugerem alguns relatórios técnicos da SPHAN9. O que ficou evidente com base nos relatórios consultados e entrevistas realizadas na cidade é o fato de que toda mobilização pela preservação cultural tenha partido sempre de uma liderança local, que de alguma maneira trabalhou pela conscientização patrimonial, na articulação entre a comunidade local e as ações institucionais, como a criação da Associação dos Amigos de Pilar de Goiás (ASAMIP), em 1995, que visava incrementar ações de revitalização do núcleo e de desenvolvimento turístico da região, ou como as doações e organização do acervo do Museu Casa da Princesa. Também foi em Pilar que percebemos um maior engajamento de profissionais da educação no que tange à luta por uma educação patrimonial que comece nas escolas, a fim de assegurar a preservação do local por meio de ações institucionais, como os projetos "Conhecer para preservar, preservar para conhecer" (iniciado em 1996) e o "Viva e Reviva" (desenvolvido pela Secretaria Estadual da Educação em várias cidades goianas, a partir de 1999), ambos em parceria com o IPHAN que, porém, não tiveram continuidade.

Além disso, a perspectiva institucional de preservação do patrimônio, por vezes, não dialoga com os sentidos de patrimonialidade que pulsam na diversidade das tradições locais, muitas centenárias. Um exemplo é a montagem de presépios e lapinhas, herança

\footnotetext{
9 Sobre o estado de consciência dos moradores quanto à preservação e ao papel do IPHAN, temos o seguinte relato no relatório técnico de avaliação e vistoria, realizado em 1995 pela Subregional do IPHAN: "As pessoas sabem vagamente que a cidade é protegida por tombamento e que para se mudar é preciso licença, mas não sabem bem de quem. Como a Prefeitura "não olha para isso e não se importa", elas também não se preocupam com a questão. [...] parece que não existe qualquer conhecimento das pessoas sobre a história do município, sua relação e importância com a história do estado, as razões de sua decadência" (Maria Cristina Portugal Ferreira. Fonte: Arquivo do IPHAN, 1995). E ainda outro relato sobre Antônio Tição, zelador do Museu Casa da Princesa à época: "O Sr. Tição, nosso funcionário local, é uma pessoa abnegadíssima, para quem a Casa e o Trabalho significam a própria vida. Entretanto, a idade, as doenças, o "Abandono" institucional em que vive e principalmente, acho eu, o marasmo em que vive a cidade, transformaram sua figura representativa de tantos fatores desconcertantes: - camisa rasgada, em que apenas um botão está na casa, calças sujas e rôtas, chinelas havaianas, já que não suporta sapatos. Os óculos são amarrados com pequenas tiras... Tudo isso, casa, funcionário, cidade, dão uma dimensão exata da nossa ausência INSTITUCIONAL em Pilar de Goiás" (Maria Cristina Portugal Ferreira. Fonte: Arquivo do IPHAN, 1995).
} 
deixada por várias famílias da cidade, para a visitação durante o ciclo natalino, com encerramento no Dia de Reis. Essa prática não só perdurou em Pilar, como reserva especificidades locais. Contam alguns moradores mais antigos que, no passado, era uma prática comum as crianças se reunirem e visitarem os presépios armados nas residências, chamando na porta: - "Ô de casa! Tem presépio? - se tivessem, entravam e admiravam-no com os personagens da Sagrada Família, além dos Reis Magos, pastores, animais do estábulo e outros itens. Por causa da escassez da época, da dificuldade em encontrar peças adequadas e que combinassem, as peças eram diversificadas, incluindo animais (tigres, elefantes, cisnes, entre outros) e objetos dos mais variados (sinos, candeeiros, terços, imagens de diversos santos católicos).

Como tantas outras tradições locais de Pilar que podem ser acompanhadas com mais profundidade em Lima (2017), os presépios e as lapinhas estão em permanente refazer - reproduzindo, renovando e retraduzindo os sentidos patrimoniais da tradição e devoção familiares locais. Permitem a concretização sensorial de uma determinada identidade, por meio do compartilhamento do símbolo que é comemorado, inscrevendoo na memória coletiva. Nisso, é nítida a existência de uma patrimonialidade que define valores a essa tradição, configurando-se como resistências do patrimônio cultural local. Valores individuais (dado pelas relações familiares) e coletivos (por se tratar de um símbolo rememorado em toda cidade, como identidade do lugar).

b) Em Crixás - observamos um patrimônio material quase totalmente inexistente, pois quase todo o acervo foi demolido nas últimas décadas, sem nenhuma política pública que o preservasse. Porém, esse mesmo patrimônio, agora ausente, continua muito presente na memória, expressando-se como uma forte consciência coletiva a respeito da perda e como disputas familiares e grupais por visibilidade - expressas, sobretudo, na atuação da tradicional Folia do Divino e na produção literária local.

Situações às avessas marcaram a história da cidade: ocupações às pressas e despretensiosas, para fins de garimpagem, febre que ocasionou a fuga da população para outros lugares; reapropriação da atividade mineradora pelos ingleses ${ }^{10}$; subordinação a

\footnotetext{
${ }^{10}$ Em 1920, integrou à história de Crixás o engenheiro Helmuth Brockes e seu irmão Ferdinando Brockes. Antes disso, as minas eram exploradas de forma autônoma, inclusive por mulheres, em bateias no leito do
} 
outras Comarcas (Pilar e Itapaci); fragmentação do território, entre outras. A condição do patrimônio e o fim de muitas edificações da cidade são, em grande parte, reflexo dessas situações. Hoje, a dinâmica econômica da cidade envolve a mineração desde as primeiras lavras até a industrialização do processo de extração presidida pela multinacional Serra Grande, cuja lógica de produção insere-se no mercado global.

Diante de sua conjuntura histórica, Crixás, atualmente, possui poucos bens materiais históricos em seu núcleo original. Lima (2015) denuncia que, no curso do desenvolvimento urbano local, os moradores com maior poder aquisitivo demoliram seus bens históricos, casas coloniais, construindo em seus lugares, casas modernas "sem expressão original", conforme as palavras da autora, moradora da cidade.

Três elementos que designam alto valor memorial são centrais nos relatos coletados em trabalhos de campo realizados em 2016 na cidade: a antiga Igreja Nossa Senhora da Conceição (figuras 5 e 6), a Casa Grande (figura 5) e a Cadeia (figuras 5 e 7), as três representadas na pintura em tela de Claudiuir Fernandes Rosa (figura 5), situadas em área central, hoje, Largo da Matriz e Praça Manoel Rodrigues Tomás.

Figura 5 - Da esquerda para a direita: Casa Grande, Igreja Nossa Senhora da Conceição e Cadeia Pública, Crixás

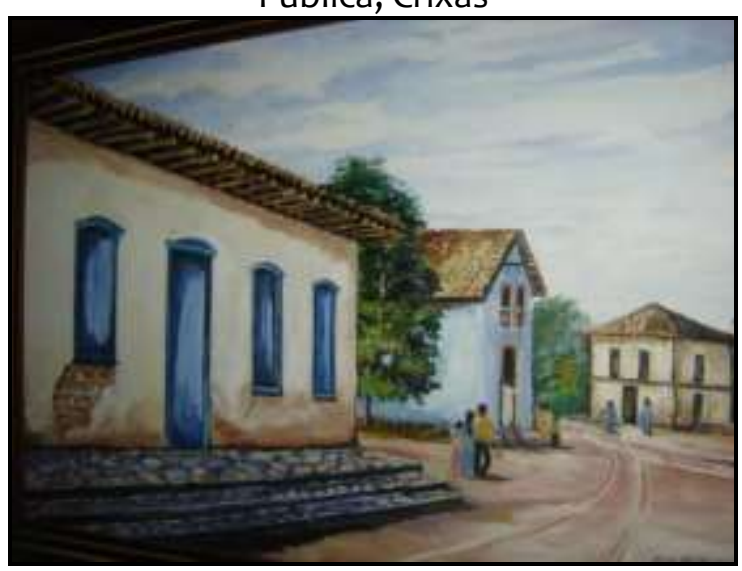

Pintura de Claudiuir Fernandes Rosa, morador de Crixás.

Rio Vermelho. As terras, então, foram adquiridas por uma Companhia Inglesa, John Taylor \& Sons, cuja exploração durou até 1923, quando os ingleses evadiram-se com todo o ouro fundido, em virtude de uma revolta no garimpo (ASMAR, 1988). 
Figura 6 - Igreja Nossa Senhora da Conceição, no mesmo local onde se encontra a igreja atual, Crixás

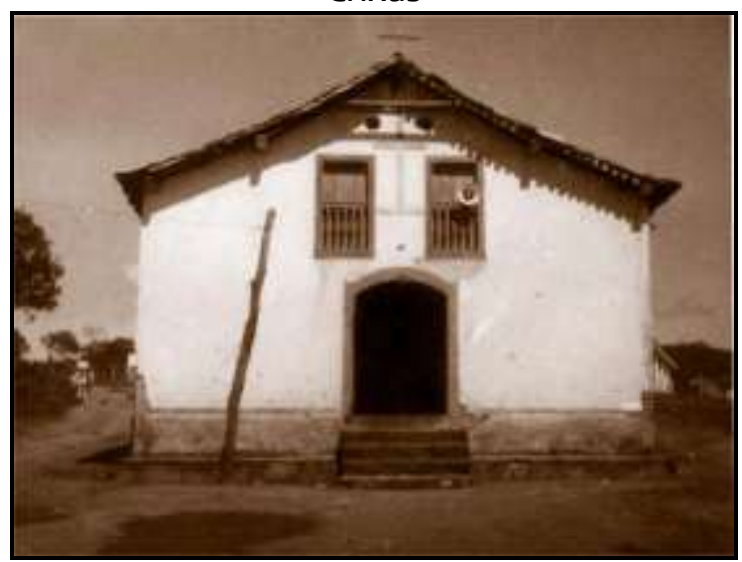

Foto: Acervo pessoal de Rômulo Xavier Lima.

Figura 7 - Antiga Cadeia Pública, já demolida, Crixás

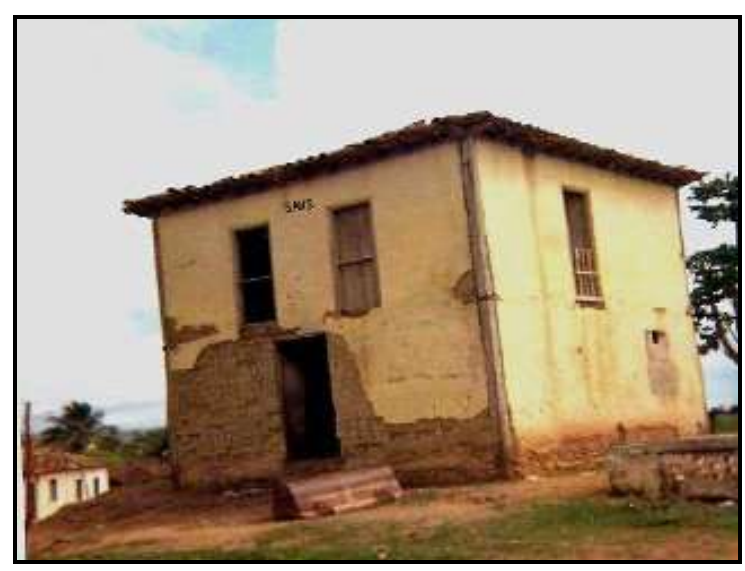

Fotos: Acervo pessoal de Rômulo Xavier Lima (sem data precisa).

Figura 8 - Casarios em Crixás, já demolidos

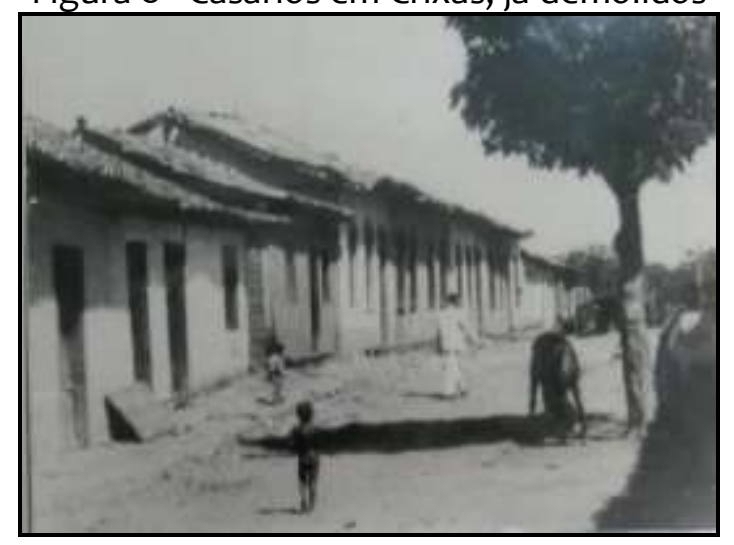

Foto: Acervo pessoal de Rômulo Xavier Lima (sem data precisa). 
Figura 9 - Espaço Cultural Ursulino Leão - o “casarão". Única edificação do período colonial mantida na cidade de Crixás, cujo projeto de restauro foi executado pela mineradora Serra

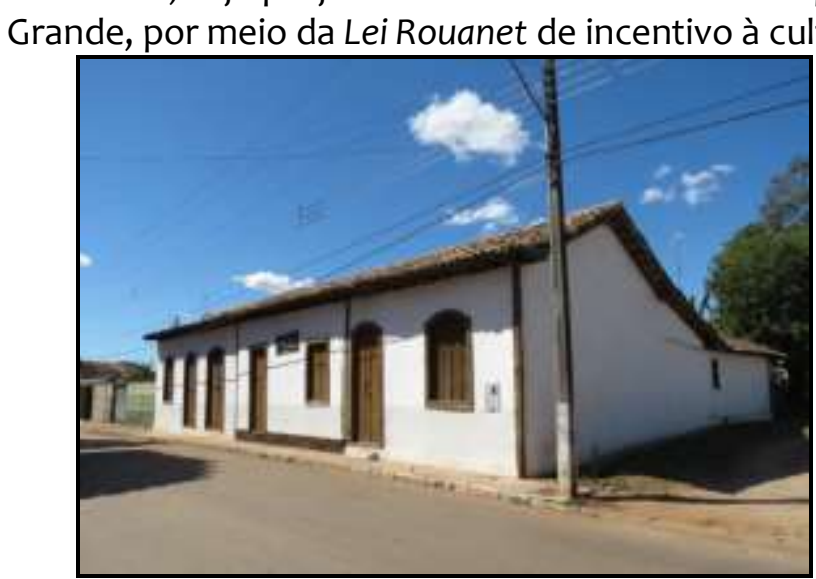

Foto da autora, 2015.

A recente consciência e o despertar de um sentimento de perda por parte de muitos moradores, agentes e representantes políticos em Crixás, bem como em Pilar de Goiás, deve-se também ao fato de que outras cidades tornaram-se referências históricas, culturais e turísticas, e receberam notoriedade midiática e institucional. Na forma de pensar de muitos moradores, isso também poderia ser realidade em sua cidade. Assim, as demandas contemporâneas contribuem para suscitar reivindicações memoriais, e a visibilidade institucional, por vezes, é a força de impulso para que se valore internamente. Como afirma Lima (2015, p. 63), no seguinte trecho: "perdendo assim nossas divisas que são sempre relatadas pelos nossos jovens que, após tomar consciência desses valores, ficam recolhendo fotos antigas e lamentando a irreparável perda" (LIMA, 2015, p.63). E expõem os entrevistados: "Nós demoramos a desenvolver nessa área, como a Cidade de Goiás, que é mais ou menos da mesma época também, um pouco mais velha, tem um acervo histórico muito grande. E o nosso foi acabando" (FARIA, 2016, informação oral).

Nos limites do que foi observado, e como já mencionado aqui, há uma forte tentativa de aglutinar o local do patrimônio edificado ao patrimônio efetivamente revivido no cotidiano. Em Crixás, o local de referência das festas sempre foi a Casa Grande - elemento importante na memória dos crixaenses, demolida em 1972 para dar lugar ao Centro Catequético da Paróquia. Foi um casarão colonial construído no século XVIII para tornar-se sede das ocasiões festivas que já eram uma constante desde o antigo Arraial. 
Um dos entrevistados relatou o impacto da demolição da Casa Grande em duas das principais tradições da cidade, a saber, a folia do Divino Espírito Santo e as Cavalhadas:

Então, houve aí uma ruptura geral relacionada com as tradições de Crixás. Com o fim da Casa Grande, automaticamente a folia perdeu força e as Cavalhadas de Crixás também, porque pra muitas pessoas não fazia sentido, que foi quebrada uma tradição e as Cavalhadas estavam inseridas nessa tradição. (MACIEL 11 , 2017, informação oral)

A Casa Grande e a Festa do Divino eram percebidas como se fossem fundidas numa só dimensão espaço-temporal existencial. "Todo mundo que queria fazer uma festa, tinha a Casa Grande. Ela era a casa do povo" (RODRIGUES ${ }^{12}$, 2002, informação oral). Não foi por acaso que, com a demolição da Casa Grande, a festa e a própria folia tenham deixado de ocorrer por doze anos, retornando somente depois de inúmeros esforços de algumas famílias.

O valor atribuído à memória da Casa Grande está no fato de que as lembranças associadas a ela estão correlacionadas a um acontecer que ainda se manifesta no presente, no cotidiano do lugar, na preparação dos doces e bolos da festa, nas Catiras e Veadeiras ${ }^{13}$, entre outros, apesar da saudade gerada pela ausência: "Eu tenho saudade demais desse tempo. Que amanhã é a missa do Divino. Era o dia da mesada de doce. Aí ia pra Casa Grande, é a hora que eu sinto a falta" (FERREIRA ${ }^{14}, 2002$, informação oral).

\footnotetext{
"José Manoel Carvalho Maciel era Presidente da Comissão de Folclore e das Cavalhadas de Crixás no período em que foi realizada a entrevista.

${ }_{12}$ Matheus Seabra Rodrigues, folião de Crixás em entrevista cedida ao documentário "Viva todos que prestaram atenção", de 2002.

13 Catira: "É dançada ao som da viola e pandeiros e caracteriza-se por ser animada e barulhenta. Os parceiros do Catira sapateiam com força sob aplausos de todos cantando modinhas que remetem a acontecimentos, como amores desfeitos ou platônicos, ou de cunho irônico". Veadeira: "É semelhante à Catira, porém o sapateado é mais rápido" (LIMA, 2015, p. 70).

${ }^{14}$ Tia Eulâmpia (in memorian), esposa do Tio Joca, família tradicional de Crixás, em entrevista cedida ao documentário "Viva toos que prestaram atenção, e 2002.
} 
Figura 10 - Dona Eulâmpia mostrando como se faz o "fiós"15. "Nasci na era de 1915. [...] Quando eu entendi por gente já fazia esse fiós na Casa Grande. [...] tem que ser bem amassado pra não ficar caroço"

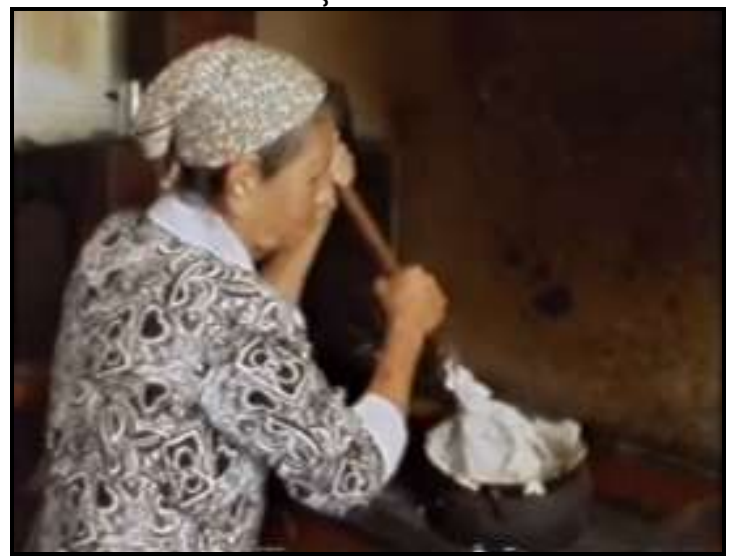

Fonte: Documentário “Viva todos que prestaram atenção" - frame de vídeo, 2002.

Figura 11 - Folia do Sertão no giro da Folia do Divino Espírito Santo, em frente à Casa do Tio Joca, lugar de referência cultural em Crixás

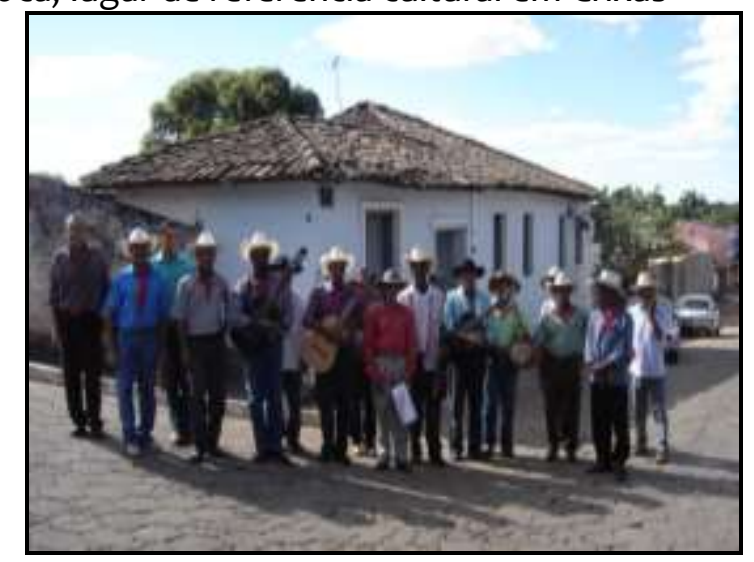

Foto: Rômulo Xavier de Lima, 2011.

c) Em Porangatu - observamos um patrimônio significativo, considerando a área do perímetro tombado, porém pouco preservado, marginalizado dentro da cidade, cujas vozes que o prestigiam são de uma pequena minoria, uma ala tradicional da cidade, diante da indiferença geral.

\footnotetext{
${ }^{15}$ Não encontrei referência deste doce em outro local no Brasil. Contudo, tudo indica que a receita é uma derivação da "filhós", um doce do receituário típico português, principalmente nas regiões do Alentejo, Beira Baixa e Trás-os-Montes. Em Portugal, as filhós fazem parte da memória afetiva, cada família tem sua receita da iguaria, que passa de geração para geração, além de estarem associadas a diversas festas, sobretudo, ao Natal.
} 
A década de 1940 é o ponto de partida para grandes transformações econômicas e espaciais da cidade, primeiramente com a institucionalização da Colônia Agrícola Nacional (CANG), que deu origem ao município de Ceres, e depois, mais efetivamente com a construção da rodovia BR-153 (Belém-Brasília) que, em 1958, trouxe forte impacto de progresso para a cidade, tornando-a um dos mais fluentes centros urbanos do Médio Norte Goiano.

Contrariamente ao que se possa pensar sobre a modernização do território porangatuense, os rumos dessa nova ocupação na direção da rodovia possibilitaram, por algumas décadas, a manutenção do núcleo histórico, outrora denominado Arraial do Descoberto da Piedade, e hoje pejorativamente chamado de “Cidade Velha". Esta, perdeu sua condição geográfica de zona central, portanto, atualmente, caracteriza-se como conjunto urbano, vinculado à atividade monofuncional de moradia: bairro antigo. A modernização e a ampliação da cidade conduziram paulatinamente a área do Arraial do Descoberto à marginalidade, pois, embora tenha sido transformada em área de proteção patrimonial, permanece em situação de precariedade e descaso, sendo inclusive, inscrita na lista de patrimônio em risco da World Monuments Fund (WMF).

O núcleo original da cidade foi delimitado e tombado pela Lei municipal 590/84, de 18 de abril de 1984, a qual o declara patrimônio histórico do município de Porangatu. Suas edificações apresentam arquitetura vernacular local, exibindo materiais, técnicas e recursos próprios, com características das edificações típicas similares às das cidades coloniais no interior de Goiás já consagradas por sua relevância arquitetônica.

O Plano Diretor Municipal, no artigo 66, parágrafo $2^{\circ}$, considera, como Áreas Especiais de Interesse Histórico e Cultural, a área delimitada do Descoberto "com seu conjunto arquitetônico, os edifícios históricos caracterizados pelo antigo Fórum, a antiga Cadeia Pública, a Praça e a Igreja Nossa Senhora da Piedade, o Casarão, a Praça do Poço do Milagre e a antiga Casa dos Correios, bem como as áreas lindeiras às citadas" (PORANGATU, 2007, p. 23). 
Figura 12 - Igreja Mariz Nossa Senhora da Piedade atualmente, Porangatu

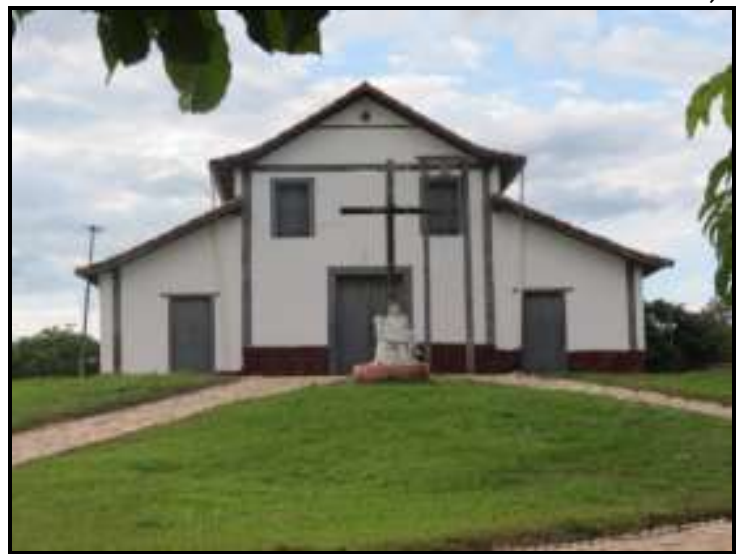

Foto da autora, 2014

Figura 13 - Centro de Tradições (Casarão), onde atualmente funciona o Museu Municipal Ângelo Rosa de Moura, na Cidade Velha, Porangatu

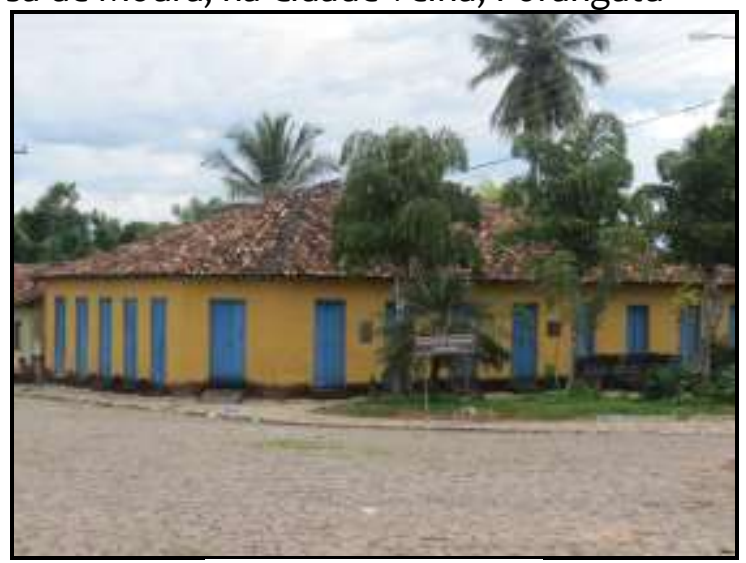

Foto da autora, 2014 .

Entretanto, atualmente, boa parte da área tombada já não apresenta as características arquitetônicas originais e os bens que ainda se mantêm enfrentam a ação corrosiva do tempo, sem nenhuma ação de preservação/conservação por parte do poder público ou privado. No núcleo histórico, restam poucas edificações que ainda não tenham passado por intervenção de reformas autônomas que as descaracterizaram, como mudança da fachada, instalação de portões automáticos, entre outras. Há inúmeros casos que apresentam um agravado risco de desmoronamento, e casos de demolições e construção de novas edificações em terrenos onde as antigas edificações entraram em colapso. 
Além disso, o local carrega o estigma da pobreza e do descaso por parte da própria população local. O Arraial do Descoberto é extremamente marginalizado e pouco se fala em uma memória de Porangatu direcionada afetivamente para o antigo povoado. Ao contrário, na percepção da população, de forma geral, trata-se da vila dos pobres (daqueles que não possuem condições financeiras para se estabelecerem em outro lugar), ou de "viciados", por, de fato, viverem ali alguns indivíduos que fazem uso de drogas e entorpecentes.

Figura 14 e 15 - Casas em ruínas ou modificadas, construídas no início da ocupação do Arraial do Descoberto, no perímetro tombado da Cidade Velha, Porangatu

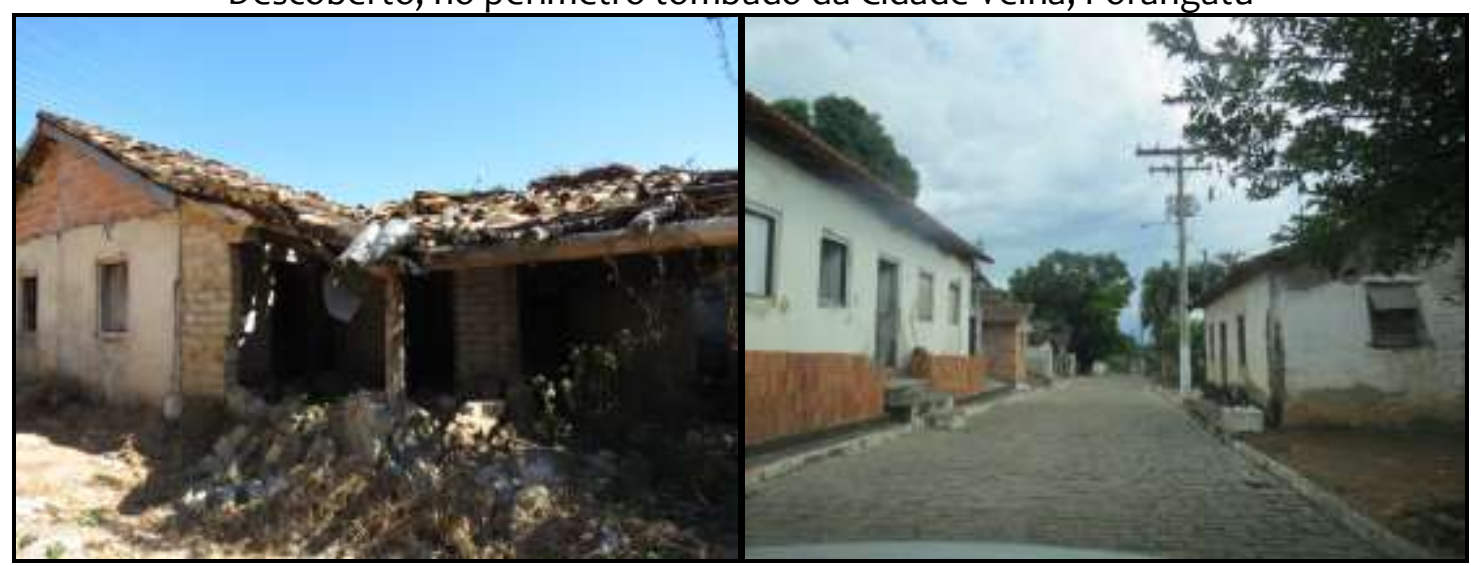

Fotos da autora, abril de 2014.

Figura 16: Cadeia Pública abandonada, Cidade Velha, Porangatu

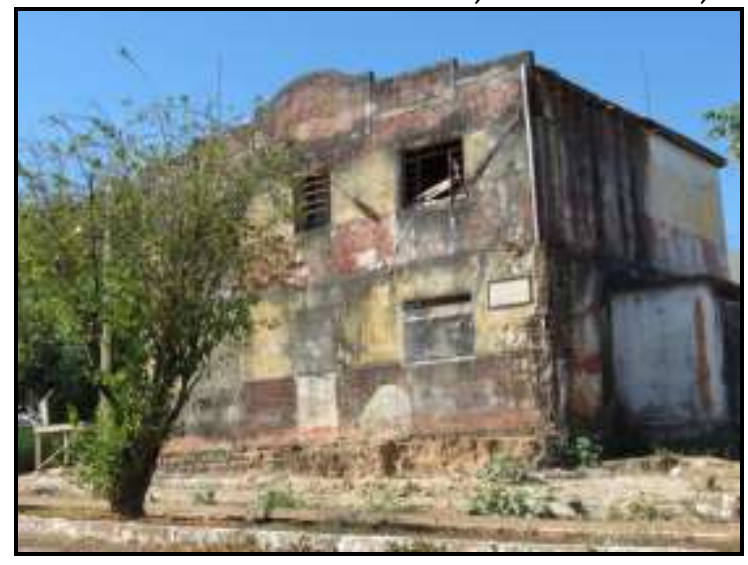

Foto da autora, bril de 2014 . 
Figura 17: Casarão restaurado com projeto de uso para Museu Arqueológico, Cidade Velha, Porangatu

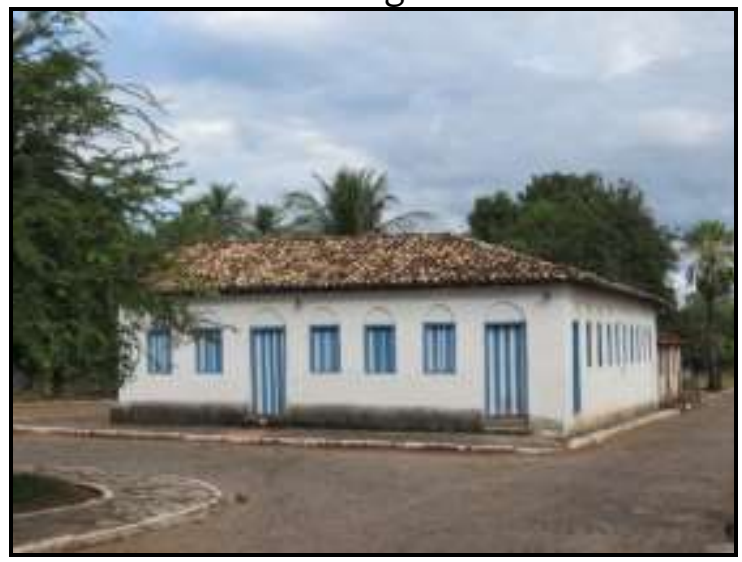

Foto da autora, abril de 2014.

A expansão urbana de Porangatu tem relação quase simbiótica com o grau de deterioração do patrimônio edificado no núcleo original da cidade, transformado em região periférica. Nas palavras de Almeida (2014, p. 02), Porangatu estaria “de costas para o Descoberto". Em primeiro lugar, essa condição está relacionada à própria “configuração geográfica que a cidade apresenta: o Descoberto de frente para o poente, e Porangatu voltada para o nascente". Segundo, porque a atual Porangatu "se desenvolveu de maneira a 'esquecer' o passado de 'inglórias', plasmado na 'velhice' e pobreza do Descoberto".

A representação que se criou do antigo Arraial do Descoberto não permite que a coletividade dos moradores de Porangatu esteja imbuída na luta pela valorização local. Em contrapartida, a comunidade da vila, incentivada pelos moradores mais antigos, descendentes dos primeiros habitantes do período colonial, ou de famílias tradicionais, reagem a esse estereótipo e reafirmam sua posição de relevância histórica e cultural.

Por meio das entrevistas realizadas com moradores dos bairros das partes mais recentes da cidade, e com ex-moradores, notei um nítido desprezo pelo antigo centro histórico. A fala dos sujeitos entrevistados evidenciam que os mesmos não se reconhecem ali e até atribuem sentidos pejorativos ao lugar, o que, a princípio parece negar a ideia de resistência do patrimônio pela memória coletiva. Mas a própria negação é negada quando, ocasionalmente, o Descoberto é lembrado como lócus de práticas culturais e educativas importantes para toda a cidade. 
A memória transita em meio a manifestações culturais que favorecem os vínculos comunitários no lugar, sobretudo aquelas que se realizam no núcleo histórico. As referências patrimoniais imateriais identificadas em Porangatu acenam, principalmente, para as festas e comemorações anuais realizadas na cidade. O município já conta com um calendário definido de celebrações, no qual o Arraiá do Descoberto, festa junina realizada na área do Descoberto, se destaca como um dos mais importantes e atrai milhares de festeiros todos os anos, da cidade e de vários municípios ao redor. Destacamos ainda, as iniciativas comunitárias, como por exemplo, a festa da Boa Vizinhança, em comemoração aos santos juninos, com novenas e partilha de alimentos trazidos de casa.

O Arraiá da Boa Vizinhança, de caráter mais comunitário e religioso, teve início como uma tradição familiar há aproximadamente vinte anos. Geralmente, participam dessa festa apenas um grupo restrito, moradores do bairro e membros da comunidade religiosa local, a Igreja Matriz de Nossa Senhora da Piedade. Todos os anos há o sorteio de quem será o festeiro do ano vindouro, assumindo a responsabilidade da organização da festa em frente a sua residência. Essa festa reforça o sentimento comunitário e de valorização do lugar, pois, ainda que o festeiro sorteado resida fora do sítio histórico, a novena e a festa obrigatoriamente devem acontecer no entorno da Matriz. Este é um exemplo de que apesar de, por vezes, estar desapropriado de sua base material, o patrimônio se reconstrói, se recria, e se reelabora no presente das cidades.

Figura 18 - Quadrilha da Terceira Idade no Arraiá do Descoberto. Grande ajuntamento de pessoas cerca o quadrilhódromo na Praça do Milagre, Porangatu

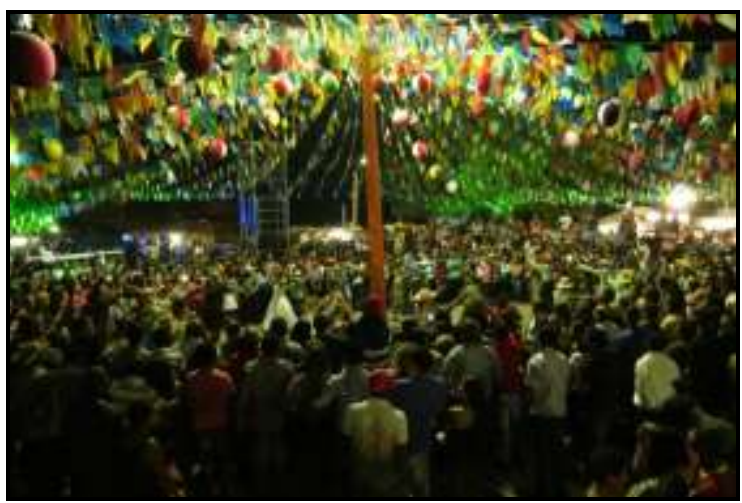

Foto da autora, 2015. 
Figura 19 - Altar a Santo Antônio, São João e São Pedro no Arraiá da Boa Vizinhança, Porangatu

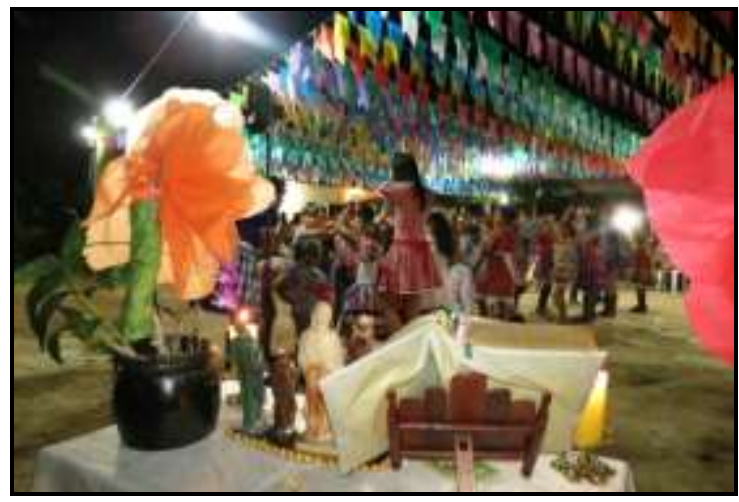

Foto da autora, 2015.

A prática do artesanato local, como cestaria, bordado, cerâmica e, notadamente, o ofício das fiandeiras, transmitido de geração em geração, consiste também em expressão da cultura local que resiste no Descoberto. O antigo Centro de Tradições (figura 13), antigo casarão na Cidade Velha, exerce significativo respaldo às atividades culturais reconhecidas como costumes tradicionais do povo porangatuense. De acordo com dados obtidos em entrevista com o Secretário de Cultura do período da pesquisa, há um certo empenho na realização de eventos culturais no Centro de Tradições com o objetivo de atrair visitantes e fazer o lugar e o acervo conhecidos aos alunos das escolas públicas.

Como foi indicado no início deste tópico, há uma minoria entre os moradores da Cidade Velha que manifesta resistência nas questões que se referem ao patrimônio local. Ainda residem no núcleo histórico algumas famílias pioneiras, consideradas detentoras de uma memória histórica sobre o Descoberto. Uma delas, há anos zela pela Igreja Matriz e é muito benquista pela comunidade religiosa. Uma das moradoras mais velhas é conhecida por narrar histórias sobre a vinda de João Leite, sobre o Nego Dunga (personagem da lenda local), sobre o garimpo, sobre a construção da capelinha e da Igreja de Nossa Senhora da Piedade, sobre a Guerra do Paraguai e a chegada de novas gentes, sobre buscar água no Poço dos Milagres (um local simbólico na praça antiga), entre outras. Entretanto, essas histórias contadas e recontadas aos grupos escolares e pesquisadores que a procuravam, de certa forma, ocultam outras tantas histórias que dizem respeito à 
ocupação do Descoberto da Piedade e à formação da sociedade local (ALMEIDA ${ }^{16}, 2016$, informação oral).

O risco desse processo é supervalorizar a história oral transmitida por alguns sujeitos eleitos como guardiões da memória e deslocar a participação de outros sujeitos na história local. Ainda segundo a entrevistada, esses sujeitos fazem parte de uma memória invisibilizada. Enquanto doze famílias antigas construíram uma espécie de "monopólio da memória”, deixaram à parte gentes como a dona de um bordel que existiu ali, negros descendentes de escravos que ainda vivem ali, indígenas que habitavam a região antes da entrada dos bandeirantes, entre outros sujeitos esquecidos, invisibilizados, que adentraram a região já no século XIX, pelo desenvolvimento da pecuária.

Nesse sentido, a dinâmica da memória do Descoberto em Porangatu caracteriza o que Pollak (1989) considerou como enquadramento da memória coletiva - quando, por meio de operações de seleção, organização e uniformização da multiplicidade de significados atribuídos ao passado, há um esforço para solidificar e dotar de duração e estabilidade uma determinada memória, de forma que ela represente o conjunto da sociedade, em detrimento do que o autor nomeia como ‘memórias subterrâneas'.

\section{Considerações finais - a memória como resistência do patrimônio}

O ponto de partida deste artigo foi a ideia inicial de uma resistência do patrimônio pelo viés da memória, e de que essa memória extrapola a perspectiva institucional do patrimônio na prática, se manifestando a partir do que é constituinte do lugar. Uma das etapas da pesquisa que deu origem a esse artigo foi reportar os elementos das cidades que ainda permanecem na paisagem e fazem parte da história e do cotidiano local, e como as políticas de patrimonialização foram (ou deixaram de ser) conduzidas.

\footnotetext{
${ }^{16}$ Maria Juliana de Freitas Almeida é professora do curso de História da Universidade Estadual de Goiás, Campus Porangatu.
} 
Os patrimônios que conformam a paisagem desses espaços conservam em si características de resistência, não por si mesmos, mas pela memória de uma coletividade urbana que lhes atribui valores e sentidos. Não podemos ignorar que "as lembranças se apoiam nas pedras da cidade” (BOSI, 1994, p. 439) e essas 'pedras' são contextualizáveis na história e na vida urbana, que estabelece seus próprios usos.

O patrimônio edificado, mesmo ausente na paisagem, continua ressoando, às vezes em meio às histórias de acontecimentos vividos pelas pessoas, às vezes como lamento e contestação, mas sobretudo nas tradições locais, como as festas religiosas dessas cidades. Essa análise encontra-se pormenorizada em Lima (2017). Cabe aqui apenas ressaltar o desenvolvimento de um modelo de análise que explicitou as formas e os tipos de relações que tais manifestações constroem com o patrimônio material e com a memória de seus moradores sobre o lugar, se constituindo como seu 'patrimônio próprio'. O lugar, em seu caráter de permanência, produz a condição sine qua non para a preservação também da festa e de seus rituais.

Além disso, os trabalhos de campo realizados nessas cidades goianas também atestaram que, para as pessoas do lugar, nem sempre é a longevidade da manifestação que as determina como tradicionais ou não, como sugerem a perspectiva institucional, os órgãos de preservação e outros estudos culturais, que se baseiam em alguns critérios para a pré-definição do que é patrimônio.

Existe uma ‘comunidade de sentimento' nessas manifestações, que dialoga com diferentes saberes locais (culinária, técnicas de produção, práticas de curas, artes, linguagens, religiosidade, entre outros) enredados nas práticas cotidianas. Essa comunidade de sentimentos, atrelada à perspectiva de lugar, foi identificada nos trabalhos de campo, fornecendo uma visão alternativa para o entendimento sobre o patrimônio cultural goiano.

As festas revelam a resistência do patrimônio, na medida em que permitem aos grupos sociais partilhar o que acreditam ser esse algo em comum: uma origem, uma memória, uma história comum. Em cada uma das cidades da pesquisa, as festas apresentaram conexões com o espaço onde se realizam, mostrando que a memória sobre 
elas se articula na construção de uma 'essência' do lugar. As rezas e cantorias com letras que remetem ao universo do lugar, as comidas típicas e modos de fazer, danças e gestos que também expressam relações de pertencimento local, contos e causos de acontecimentos na festa, são exemplos.

A lembrança que traz o passado à tona no presente não diz respeito apenas ao aspecto ritualístico que caracteriza as crenças, mas também ao cotidiano, captado e envolvido na produção do acontecer festivo. As práticas rituais e de cultos, num ciclo contínuo e anual, são uma representação de um passado secular vinculado a um presente compartilhado por uma fé cotidiana. Os locais do patrimônio também integram essa dinâmica: as ruas por onde passam as procissões, os fornos onde se assavam os bolos tradicionais das matinas, a igreja onde há a entrega da folia, os sinos que estabelecem uma forma de comunicação centenária, entre outros. Esses locais interagem com a festa, impregnando-os de significados e revelando o efeito pedagógico necessário e oportuno dessas tradições diante da ausência de uma educação patrimonial formalizada.

Disso, concluo que a resistência não se traduz necessariamente pela permanência material desses elementos, mas sim em como se situam na percepção cotidiana das populações, estabelecendo os lugares na significância histórica do presente e 'dentro de si' (MERLEAU PONTY, 1999).

A patrimonialidade vista e sentida em Pilar, Crixás e Porangatu é a negação do 'esquecimento' do patrimônio local, o que significa dizer que não existe um 'esquecimento' total, pois o mesmo foi afirmado ininterruptamente nas tradições, valores, ruralidades, práticas seculares que resistiram sem registro, sem tombo e sem visibilidade.

\section{Referências}

ABREU, Adair José Ataídes de. [Sem título]. [Entrevista cedida a] Luana Nunes Martins de Lima. Porangatu, 2015. 1 arquivo sonoro (48 min.), extensão mp3.

ABREU, Maurício de. Sobre a memória das cidades. Revista da Faculdade de Letras: Geografia I, Porto Alegre, v. XIV, p. 77-97, 1998. 
ALMEIDA, Maria Juliana de Freitas. Porangatu: a história, a memória e degradação patrimonial. In: Congresso Internacional de História, 4. 2014, Jataí. Anais [...] Jataí: Universidade Federal de Goiás, 2014, p. 1-9.

ALMEIDA, Maria Juliana de Freitas. [Entrevista cedida a] Luana Nunes Martins de Lima. Porangatu, 2016. 1 arquivo sonoro (60 min.), extensão mp3.

ARGAN, Giulio Carlo. História da arte como história da cidade. 4. ed. São Paulo: Martins Fontes, 1998.

ASMAR, José. Crixás, do berço de ouro à luta pela vida. Goiânia: [s.n.], 1988.

BAUMAN, Zygmunt. Comunidade: a busca por segurança no mundo atual. Rio de Janeiro: Jorge Zahar Editora, 2003.

BAUMAN, Zygmunt. Identidade. Rio de Janeiro: Jorge Zahar, 2005.

BOSI, Ecléa. Memória e sociedade: lembrança dos velhos. 3. ed. São Paulo: Companhia das letras, 1994.

BRANDÃO, Carlos Rodrigues. Pesquisar - Participar. In: BRANDÃO, Carlos Rodrigues (Org.). Pesquisa participante. 8. ed. São Paulo: Brasiliense, 1990. p. 9-16.

BRASIL. Iphan inaugura obras do PAC Cidades Históricas em Pilar de Goiás. 2011. Disponível em: http://www.brasil.gov.br/noticias/cultura/2011/02/iphan-inaugura-obras-dopac-cidades-historicas-em-pilar-de-goias. Acesso em: 20 nov. 2015.

BRITO, Marcelo. Gerenciamento de núcleos históricos: gestão do desenvolvimento versus gestão da estagnação. In: DEPARTAMENTO de Patrimônio Histórico e Artístico do Distrito Federal (Org.). A construção da cidade. Brasília, 1998, 98-113.

CHAUL, Nasr Fayad. Caminhos de Goiás: da construção da decadência aos limites da modernidade. 3. ed. Goiânia: Ed. da UFG, 2010.

CHUVA, Márcia. Os arquitetos da memória: sociogênese das práticas de preservação do patrimônio cultural no Brasil. Rio de Janeiro: UFRJ, 2009.

CHUVA, Márcia. Preservação do patrimônio cultural no Brasil: uma perspectiva histórica, ética e política. In: CHUVA, Márcia; NOGUEIRA, Antônio Gilberto Ramos (Orgs.).

Patrimônio cultural: políticas e perspectivas de preservação no Brasil. Rio de Janeiro: Mauad X: FAPERJ, 2012, p. 67-74. 
COSTA, Everaldo Batista. A ideologia espacial constitutiva do Estado nacional brasileiro. Scripta Nova. Revista Electrónica de Geografía y Ciencias Sociales [En línea], Barcelona: Universitat de Barcelona, 1 nov. de 2012, v. XVI, n. 418. Disponível em: http://www.ub.edu/geocrit/sn/sn-418/sn-418-6.htm. Acesso em: 10 abr. 2015.

COSTA, Everaldo Batista; STEINKE, Valdir Adilson. Cidades históricas do estado de Goiás, Brasil: uma agenda de pesquisa. Ateliê Geográfico, Goiânia, v. 7, n. 2, 2013, p.164-195.

COSTA, Everaldo Batista da; SUZUKI, Júlio César. Materialismo histórico e existência: discurso geográfico e utopias. Revista Espaço \& Geografia, Brasília, v. 15, n. 1, p. 115-147, 2012.

DELGADO, Lucilia de Almeida Neves. História Oral: memória, tempo, identidades. 2. ed. Belo Horizonte: Autêntica, 2010.

ETZEL, Eduardo. O barroco no Brasil: psicologia e remanescentes em São Paulo, Goiás, Mato Grosso, Paraná, Santa Catarina, Rio Grande do Sul. São Paulo: Melhoramentos, 1974.

FARIA, Inácio Ferreira de Faria. [Sem título]. [Entrevista cedida a] Luana Nunes Martins de Lima. Crixás, 2016. 1 arquivo sonoro (80 min.), extensão mp3.

FERREIRA NETO, Prudêncio. [Sem título]. [Entrevista cedida a] Luana Nunes Martins de Lima. Crixás, 2015. 1 arquivo sonoro (90 min.), extensão mp3.

FERREIRA, Elisabeth Dietz Neves. [Sem título]. [Entrevista cedida a] Luana Nunes Martins de Lima. Crixás, 2015. 1 arquivo sonoro (65 min.), extensão mp3.

FREITAS, Lena Castello Branco Ferreira. Goiás e Goianidade. Aphonline, Trindade, v.1, n. 1, p. 52-64, jan./jun., 2011.

HALBWACHS, Maurice. A memória coletiva. São Paulo: Centauro, 2003.

IBGE. Instituto brasileiro de Geografia e Estatística. Cidades. Disponível em: http://www.ibge.gov.br/. Acesso em: julho de 2014.

IPHAN. Arquivo Noronha Santos. Disponível em: www.iphan.gov.br/ans. Acesso em: set 2015.

IPHAN. Relatório técnico de avaliação e vistoria da $17^{\mathrm{a}}$ sub-regional do IPHAN. Goiânia: [s.n.], 1995.

JEUDY, Henri-Pierre. Espelho das cidades. Rio de Janeiro: Casa da Palavra, 2005. 
LIMA, Luana Nunes Martins de. Lugar e memória: o patrimônio goiano entre o esquecimento e a resistência. Brasília, 2017. 397 f. Tese (Doutorado em Geografia) Universidade de Brasília, 2017.

LIMA, Maria Madalena. Crixás: nossa terra, nossa gente. 2. ed. Goiânia: Scala Editora, 2015.

MACIEL, José Manoel Carvalho. [Sem título]. [Entrevista cedida a] Luana Nunes Martins de Lima. Crixás, 2017. 1 arquivo sonoro (34 min.). Whatsapp.

MERLEAU-PONTY, Maurice. Fenomenologia da percepção. 2. ed. São Paulo: Martins Fontes, 1999.

NEVES, Honória Ferreira. [Sem título]. [Entrevista cedida a] Luana Nunes Martins de Lima. Crixás, 2015. 1 arquivo sonoro (90 min.), extensão mp3.

PAES, Maria Tereza Duarte. Refuncionalização turística de sítios urbanos históricos no Brasil: das heranças simbólicas à reprodução de signos culturais. Geografia, Rio Claro, v. 37, n. 2, p. 319-334, mai./ago. 2012.

POLLAK, Michael. Memória, esquecimento, silêncio. Estudos Históricos, Rio de Janeiro, v. 2, n. 3, p. 3-15, 1989.

POULOT, Dominique. Uma história do patrimônio no Ocidente. São Paulo: Estação Liberdade, 2009.

PORANGATU. Lei Municipal $\mathbf{n}^{\circ} \mathbf{. 2 . 2 9 2}$, de 13 de novembro de 2007. Dispõe sobre o Plano Diretor Sustentável do Município de Porangatu e dá outras providências. Porangatu, 2007. Disponível em: http://www.camaraporangatu.go.gov.br. Acesso em: ago. 2015.

RICOEUR, Paul. A memória, a história, o esquecimento. Campinas: Editora da Unicamp, 2007.

ROCHA, Ana Luiza Carvalho da; ECKERT, Cornélia. A cidade: sede de sentidos. In: LIMA FILHO, Manuel Ferreira; ECKERT, Cornélia; BELTRÃO, Jane Felipe (Orgs.). Antropologia e patrimônio cultural: diálogos e desafios contemporâneos. Blumenau: Nova Letra, 2007, p. 343-361.

SANTOS, Milton. Metamorfose do espaço habitado: fundamentos teórico e metodológico da Geografia. São Paulo: Hucitec, 1988.

SCARLATO, Francisco Capuano; COSTA, Everaldo Batista da. Geografia e patrimônio urbano: questão metodológica. Espaço \& Geografia, Brasília, v.16, n. 2, 2013, p. 369-387. 
VIVA todos que prestaram a atenção - “Festa do Divino Espírito Santo de Crixás". Direção de Carlos Cipriano e Denise Clímaco. Goiânia: Comunicação Social (UFG), 2002. 1 DVD (45 min.).

Recebido em: 07/03/2019 Aprovado em: 12/07/2019

Universidade do Estado de Santa Catarina - UDESC Centro de Ciências Humanas e da Educação - FAED

Revista PerCursos

Volume 20 - Número 42 - Ano 2019 revistapercursos@gmail.com 